\title{
Pedagogical Practice in Engineering Courses: Students' Contribution
}

\author{
Herivelto Moreira ${ }^{1, *}$, Samoara Viacelli da Luz ${ }^{1}$, Rozane de Fátima Zaionz da Rocha ${ }^{1}$ \& \\ Armando Kolbe Junior ${ }^{1}$ \\ ${ }^{1}$ Universidade Tecnológica Federal do Paraná (UTFPR), Avenida Sete de Setembro, 3165, \\ Curitiba - Paraná, Brasil \\ Corresponding author: Postgraduate Program in Technology at Universidade Tecnológica \\ Federal do Paraná (Technological Federal University at Paraná) Av. Sete de Setembro, 3165 \\ Curitiba, Paraná, Brazil Tel: 55-41-3310-4725 E-mail: herivelto.moreira51@gmail.com
}

Received: April 27, 2015

Accepted: May 29, 2015 Published: June 26, 2015

doi:10.5296/ije.v7i2.7503

URL: http://dx.doi.org/10.5296/ije.v7i2.7503

\begin{abstract}
The objective of this article was to identify Brazilians engineering students' perceptions about the relevance of pedagogical knowledge and its implications for the professional preparation. The interest in the study was due to the urgency to promote actions which can contribute to the improvement of higher education, as well as the lack of studies highlighting the students' perceptions and experiences in relation to what they consider a good class and good teaching/learning strategies used by teachers. The approach used was qualitative. The sample consisted of nine students from the 4th and 5th years of the Mechanical and Civil Engineering courses of a public university in south Brazil. The data was collected through individual semi-structured interviews. The main results allowed to reflect on how teaching and learning strategies influence to define what students consider a good class and what characterizes a good teacher. Evidence also suggests that there is a predominance of lectures through slides projection in which students do not actively participate during the classes, and as characteristics of a good teacher emerges: teachers' mastery of scientific knowledge, mastery of the pedagogical knowledge (didactics), ability to contextualize the content, to relate theory and practice, and the ability to motivate and develop good relationship with students.
\end{abstract}

Keywords: Good Teacher, Good Class, Active Learning Strategies, Students' Active Participation Engineering Courses 


\section{Introduction}

The quality of higher education has become a key issue in the international arena, especially in the United States and Europe. Several changes have occurred over the years. First, the advent of mass higher education in the 1960s, and even more so, in the 1980s produced a shift in the conception of the universities' role. It questioned the nature of the relationship between teaching and research (Henard and Leprince-Ringuet, 2008). Second, changes in the funding structure of many universities also increased the focus on the quality of teaching. The modern State, the "evaluative state" (Neave, 1998) is a State that has concerns dominated by value for money and public accountability.

Third, the student body itself has changed considerably, hence modifying expectations regarding teaching. To begin with, in most developed countries, increasing social diversity has transformed the student body at university level. Higher education is no longer reserved to the elite. Next, the Internet has globalized the market place, and institutions are increasingly competing for the best students, nationally and internationally.

Finally, the teaching and assessment methods also evolved setting challenges for teachers, which to incorporate them into their daily practices need to become familiar with new and virtual methodological approaches to promote student participation and quality education.

Higher education in Brazil, over the past decades also experienced various transformations and changes such as: the expansion of the number of vacancies, the flexibility of the system, changes in the curriculum (National Curriculum Guidelines), and changes in the criteria for student access, faculty graduate degree requirements, and systematic process of evaluation, both at institutional and national level, among other indicators. (Pachane and Pereira, 2004; Cunha, 2010).

In addition to these changes, the research literature shows reflections about the challenge of making students' participation more effective in the learning process. In many cases, it is clear that the difficulty is not related to the knowledge that the teacher has on the content of the discipline (scientific knowledge), but on the pedagogical knowledge, in other words, in the proper way to work this content to encourage student learning (Leite, 2008; 2010; Moreira et al., 2012; Moreira, et al., 2013).

Although the educational literature emphasizes that students' knowledge is the starting point for any pedagogical action, in practice there are not many initiatives. Therefore, it is essential to invest in research that enhances students' perceptions and experiences in relation to the process of teaching and learning used by teachers, because students also stand out as protagonists in the challenge of improving the quality of education. It is essential that higher education institutions invest in this kind of research, to help teachers to participate more effectively and with knowledge in curricula reformulation in the courses where they teach.

Thus, the objective of this article was to identify Brazilian engineering students' perceptions about the relevance of pedagogical knowledge and its implications for the professional preparation. 


\section{Literature Review}

Teaching in many Brazilian universities, is still very focused on the mechanical transmission of content, students performing repetitive exercises in class, and memorization of definitions and formulas. This approach to teaching, characterized by several authors (Anastasiou, 2001; Anastasiou and Alves, 2006; Cunha, 2005; Silva and Cecilio, 2007), as traditional, based on the verbal presentation of the subject content (mainly through lectures) in which both the exposure and the analysis are done by the teacher, that is, teachers present the content ready to students, without considering the intellectual diversity of knowledge in the classroom.

In contrast, in the current context of the academy, teachers in higher education, especially in engineering courses, are faced with the need to promote the development of general and specific skills in students that the labor market demands, that is, critical thinking, learning to learn, self-confidence, communication skills, teamwork, sense of responsibility and initiative, ability to make decisions, and to solve problems and conflicts.

The discourses, practices and research (Anastasiou and Alves, 2006; Lucarelli, 2000; Barbosa and Moura, 2013) advocate that teaching/learning processes that rely on the logic of mechanical transmission are not best suited to answer these requests. In this scenario, the challenge is to use teaching and learning strategies that promote deeper learning in students, as opposed to learning more superficial in nature (characterized by the mere transmission of information and reproduction).

The change in the process of teaching, from a mechanical model of transmitting knowledge to more active methods centered on the involvement of students and the construction of knowledge, implies teachers' willingness to face new challenges and review their practice, appropriating teaching and learning strategies that can assist in the training of future professionals with holistic vision, able to integrate theory and practice, through active learning and competency based.

Active learning presupposes the active involvement of students in the learning process, reading, writing, asking, arguing or being busy in solving problems and developing projects. Furthermore, within this proposal, the students must perform mental tasks at high cognitive level such as analysis, synthesis and evaluation. (Barbosa and Moura, 2013).

In short, active learning engages students in the learning process, so that they participate in meaningful activities and think about what they are doing. Although this definition can include traditional activities such as homework, in practice, active learning refers to activities that are introduced in the classroom (Bonwell, 2015).

According to Villas-Boas et al. (2012), active learning does not have techniques but have strategies. Teaching and learning strategies are defined as the way that will facilitate the transition of students from the situation they are in, to achieve the stated objectives, both of technical and professional nature, as the individual development, as a human being and as transformation agent (Morin, 2004). 
In Graaff and Christensen's opinion (2004, as cited in Villas-Boas et al. 2012, p.64), active learning and engineering education form a natural pair, because:

the engineer is educated to design and build solutions to real world problems. Originally, the act of teaching engineering, used to have very close links with their practice, but gradually the engineering education has become more and more based on theory.

Although the literature in the area and the official documents suggest that undergraduate students should use active methodologies for monitoring, and for evaluation of the teaching and learning process and the course itself, in line with the evaluation system and curriculum dynamics defined by the institution to which they belong, some doubts still linger in academia, especially, how it can be applied in engineering education, since the teachers in these courses also consider education through work and laboratories as active.

Villas-Boas et al. (2012) reported that in the Brazilian Congress on Engineering Education (COBENGE), they note an increase of work and studies on the implementation of active methodologies in engineering courses, indicating the perception on the part of teachers and of the courses, to promote teaching strategies that put the student also as protagonists of the teaching and learning process.

Therefore, the teaching strategies are resources that can help improve the process of teaching and learning in shaping the future engineer, but it will only have an impact if are connected directly to the intended objectives. In general, the most appropriate strategies considered are those that help teachers and the students to achieve the proposed objectives.

It can be said then that the central point in choosing a teaching strategy is the knowledge of the objectives to be reached. If the goal is to help students develop or enhance problem solving and thinking skills, stimulate their interest in a subject and motivate them to have a deeper approach to study, the strategies that engage students actively have consistently been considered more effective than the lecture. But the challenge is to involve most or all students in active pursuits without sacrificing the course content or lose control of the class.

\section{Methodology and Procedures}

This study is part of a larger study conducted in two phases. The first phase of the study was a descriptive quantitative survey with a sample of 230 students enrolled in the 4th and 5th years of two engineering courses (Mechanical and Civil), whose goal was to identify broad trends from students' perception on the teaching strategies used by teachers in a public university in southern Brazil.

The second phase of the study, object of this article, was qualitative and the objective was to explain and deepen the quantitative results obtained in the first phase of the study. According to Moreira and Caleffe (2008, p. 73), in qualitative research the focus of the investigation is the essence of the phenomenon and the world view is a function of individual's perception, seeking to have the participants speak for themselves, so that evidencing their perspectives with words and actions. 
The participants of this phase of the study were nine students from both engineering courses, intentionally selected (non-probabilistic sample) from a list of forty-five (45) students who volunteered their names to participate at this stage when completing the questionnaire in the first phase of the study.

Due to the procedures adopted in this type of sampling it is not possible to generalize the results obtained from the sample to the population. Therefore, the opinions of students cannot be generalized. The final sample consisted of nine students from the $4^{\text {th }}$ and $5^{\text {th }}$ years of the two engineering courses mentioned above. The decision to use students from $4^{\text {th }}$ and $5^{\text {th }}$ years was due to the fact that these students have gone through significant experiences in relation to teaching and learning at the institution. The average age of participants is 22.9 years.

The data collection technique was the semi-structured individual interviews. The interview protocol was developed from the results of the first phase of the study, since the goal of this phase was to explore the statistical results and understand students' perspective in more depth. Before starting the interviews each participant of the study signed an informed consent letter which guaranteed the anonymity and confidentiality of information. The interviews lasted an average of sixty minutes and were conducted in the university classrooms. The interviews were audio-recorded and transcribed literally and returned to the participants to ensure the validity and accuracy of the answers.

\section{Data Analysis and Interpretation}

The constant comparative method was used to analyze the data, through the software MAXQDA11. Tree categories emerged from the data presented and the attempt was to portray, as faithfully as possible, the students' perception about the relevance of the teaching role in shaping the future professional engineering and the teaching strategies used by teachers of the two engineering courses in the institution researched.

\subsection{The relevance of teachers' pedagogical knowledge: implications for engineering professional preparation}

In considering the question of teachers' pedagogical knowledge to teach classes and conduct activities in the classroom, the participants' opinions were divided into three central issues to the teaching and learning process in higher education: teachers' didactics, students' active participation, and the theory and practice relationship. Each of them will be treated separately below. Teachers' didactics was greatly emphasized by the students. They stated that most teachers master their subject (scientific knowledge), but many do not have didactics (pedagogical knowledge), and thus, do not prepare quality lessons. The opinion expressed below demonstrates this point:

a good teacher for me is one that has didactics in the classroom. Many teachers have the knowledge of the subject, but do not have didactics, and even personal characteristics, some are shy and some do not prepare lessons with quality (Student of the 5 th year). 
While criticizing the lack of teachers' didactics, students tried to work out what this meant for them, and provided some examples of what they considered important to enhance the motivation to learn. It was observed in the reports that students were aware of what would be the didactics of teaching in the classroom and could verbalize the attitudes of teachers in relation to what we dealt in the literature review, for example, choosing the most appropriate teaching strategy to work the contents. This issue was very clear in the speech of the following student:

A good lesson is not given only with slides, because slide gives us sleep and the teacher does not come and talk to you. Teachers have to give the boundary conditions for you to come to the conclusion. He/she has to show you different sources and urges you to research more about it. I think a good class must have at least some exercises, because we just see the theory, but cannot apply it. And not only exercise that are in the text books! But also examples that happens in reality of what he/she is showing (Student of the 5 th year).

In the above account, the student provides an example of the type of class that he considers most useful and even the type of teaching strategy that the teacher should use. In all participants' answers, was implied a request that refers to the need to introduce more practical activities, targeted for student participation in the process.

In the statement below, it was possible to perceive that the active participation of students in classroom activities is a very important factor for motivate them to study, to understand the content by deepening the proposed themes, be autonomous in the search for information and exchange of information between peers and teachers.

The teacher should present the theme, show real cases, do exercise in the classroom and propose a project. If he does so, I have the base I need to develop my skills in a particular subject. This is highly practical and if it happens I would actively participate and sit in first row in the classroom (Student of the 5 th year).

It is important to emphasize that students no longer wish to be only listening the teacher talking. They value and know that their learning also depends on their participation and involvement. This can be seen in the following report:

There are many lessons that the teacher talks, talks and talks, but we only learn the content of the lessons at home, and to be only listening add nothing to our learning. In fact, I go to classes only to have the guidance of what to study. ( Student of the 4th year).

The preference and the desire to work collaboratively in teams and participate in an active way, to exchange information, experiences and discuss with peers and teachers, also was present again on student reports:

I prefer group dynamics in the classroom. For example, I found that the best class I attended was in the subject of "Project Methodology". The teacher worked through group dynamics, and divided the students into groups. This subject I really found very good. The classes that you participate actively are more interesting than the ones that you just sit listening to the teacher (Student of the $5^{\text {th }}$ year).

Several authors (Asokanthan, 1997; Göl and Nafalski, 2007; Krivickas, 2005) argue that when learning is directed for interaction and cooperation among students to fix goals and objectives together and seek common ways to achieve them, the results achieved are better than when tasks are organized individually, that is, when each student views the task alone. 
Another aspect addressed in regard to learning was the understanding that the teacher should try to address the reality that the student will find in the workplace. Therefore, practices related to daily life, student's universe, professional practice, and others, which lead to the practical field out of the classroom, are understood as learning facilitators. This corroborates the results of more recent studies in the area and what the National Curriculum Guidelines for Engineer Training (BRAZIL, 2002) proposes. The following student's account shows this concern:

It is when the teacher brings reality into the classroom. I had a teacher that I considered very good, he always tried to show a practical example, although his subject was theoretical. So you see it is more palpable, you care more for that content, as you see where it will be applied (Student of the 5th year).

The data also revealed that students give special value to the relationship between theory and practice, which means they understand that learning happens whenever this relationship explicitly occur during class. Other students said that learning becomes easier when the subject to be learned is executed directly in practice. The speech below is representative of the importance students attached to the relationship between theory and practice.

If I think about putting me as a teacher, it must be very difficult to convey such information (theoretical), but if we consider that is a two hour lesson, it is important then, to have an involvement in practical activities, not only exercises, but real cases, and applications (I think this is very important) to solve problems, to talk with colleagues and not only solve the exercise for teachers' to correct, but do together (Student of the 4th year).

Thus, the relationship between learning and practical action stands out that theory and practice should go together throughout the undergraduate program. Knowledge and doing must be interconnected. Teachers using teaching strategies that promote the link between theory and practice should be considered as good examples for what you want in the training of future professionals.

Another important aspect related to teaching strategies in students' opinion was what they considered a good teacher. The answers to this question and follow-up questions about the issue provided an understanding of what students consider to be a "good teacher" in engineering courses. Again, several issues were cited such as the organization of teaching activity, the use of methodologies that students actively participate and the relationships between the content of the subjects with the professional contexts. The following report is representative of students' opinions:

The teacher should be a person who can instigate you. He/she cannot only put you through the content as it is in the book or make a summary of the book and bring it to you. He also should bring you knowledge that he has about the world; about his/her own professional experience! This is why it is very important for the teacher to be focused in a practical area. Whatever is the subject, the teacher has to already experience the practice and how he used the theory in practice. And this is one of the points that is a little behind here in our institution. Anyway, the teacher in higher education must, in addition to bring the content to make the student research, maybe even motivate the student to learn more about it. You must be capable to exercise your freedom as a higher education student and research on a particular topic. (Student of the 5th year).

The comments made by students coincided with the results of other studies related to what is meant to be a "good teacher." On a research conducted by Castanho (2000), the author shows the characteristics of outstanding teachers: concern with the relationship between theory and 
practice and interdisciplinarity; quality in teacher-student relationship; interest regarding student learning; provide easy and enjoyable learning; show scientific advances in a competent, dynamic and articulate way, organized in relation to their work in the classroom, and demonstrate love for knowledge.

Evidences in this study indicate that the motivation to learn is also related to the methodology used by the teacher, that is, the creative and dynamic teacher who presents news and cares about the student keeps the students' attention during class. By changing their teaching practice from mechanical transmission to mediation, the teacher needs to be dynamic and creative.

For this, the teacher should perform activities that address students' individual differences, that is, to request students' participation in various ways. The teacher can, for example, encourage the initiative of some to ask questions in class, charge others to bring new information, and ask others to submit reports and summaries of lessons.

\subsection{Teaching and learning strategies: the prevalence of the traditional}

In an attempt to identify the various aspects involved in the process of teaching and learning, we asked to the participants which were the teaching strategies most used by teachers. All respondents reported that the classes were mostly based on lectures through the projection of slides and use of the blackboard. The following account is representative of students' views:

It is the lecture. That I think is the worse strategy. The teacher turns on the projector with a slide prepared two or three years ago and never updated it. This is dull, it's horrible. Of course there's no way to prohibit it, because there are teachers who teach well with this strategy, but most of the classes I took here was in this model: Power Point. But for me it is this kind of lecture, simply with the use of slides, in which the teacher never updates the slides (Student of the $5^{\text {th }}$ year).

Although, students consider that teachers are extremely intelligent and have the necessary scientific knowledge to lead their subjects, they also realized that many of them are not very interested in the didactic-pedagogical aspects of learning. For the students, teachers of these courses are traditional teachers. This thought can be seen in the following statement:

I think it is not necessary entering the realm of knowledge, technical and theoretical basis, because here all teachers have. I never met a teacher that when I needed help did not know the subject. Maybe they do not know the answer on the spot, but they know where to find the information to give you later on. Teachers' scientific basis is very good. What is lacking for many teachers is to express themselves better and explain better what they know. (Student of the 4th year).

Some students interviewed think that the use of slides through Power Point in class could be narrowed to theoretical subjects and subjects of the humanities area, which also may not be the case. It is not because the subject is considered predominantly theoretical or located in the humanities that the use of such strategy is recommended.

In short, students' accounts corroborate the opinion of several studies that demonstrate the need to overcome the traditional teaching methodologies, predominantly based on lectures. While the lecture is still considered efficient, Duch et al. (2001, p.5) attribute their persistence 
in higher education, mainly because it is familiar, easy and recalls how teachers learned (apprenticeship of observation). However, these methodologies favor very little the development of process skills to complement content knowledge.

Following the analysis, the next category addresses the students' opinions on the kind of class they believe they learn more and the kind of classes they consider unproductive for learning.

\subsection{Productive and unproductive lessons: beyond the traditional}

When we ask to the interviewees about the types of classes they considered most interesting and motivating, their answers focused mainly on the idea that they learn more easily what they like, and again when the teacher uses teaching strategies that emphasize student participation in the process. In the following account was possible, again, to find characteristics of the traditional pedagogy,

The lesson which you have only to copy the content from the blackboard, that you could just take the content and read, especially in the core subjects. I've had a teacher, for example, that he used just to write the content on the blackboard and did not discuss it, and when the students began to get the book and photocopy it, and he saw that no one else was coping and doing nothing in class, he exchanged for a book that was not in the library. (Student of the 5th year).

Respondents also considered the teacher, depending on their attitudes, responsible for the student's interest in a particular subject and that the dedicated teacher has positive influence on learning. This issue can be seen in the following quote:

The motivation was due to the way the teacher conducted the classes. What I think, for example, if the teacher teaches well, the student will do things, will engage and will work hard to give back what the teacher is trying to do. Now, if the teacher does not engage or does not teach or not comply with the time, the student will also not strive. "Why am I going to do this if the teacher did not do?" There is the question of separating things that we think is important or it is so important and that we end up devoting more and those that we end up leaving to study in the last days before a test (Student of the 7th year).

On the other hand, the lack of interest by the teacher, according to the respondents, negatively influences on student learning:

I think in the area of mechanical engineering it is more the subject, and the teacher. Teachers, who teach subjects which are more used in humanities, electrical engineering and so on, need to be creative and teach using different strategies, because if they stay teaching the same thing in the same way ever, the student will be not interested and will not learn. It is a question of how to teach the subject. You need to make that subject attractive for those who are not interested. So maybe videos, perhaps making something that draws our attention to the subject (Student of the 5th year).

The teacher/student relationship also in higher education, play a key role in learning. Therefore, it is possible that the positive or negative attitudes of teachers work as a motivation or demotivation for the students, leading them to change their levels of effort, and thus in academic performance (Rego, 2001; Bordenave and Pereira, 2002). This idea is confirmed in the following quote: 
Wow! There were some subjects that I really got motivated. Those were the teachers that I kept in touch more often and were teachers who were more open (to receive students). Which subjects? Let me remember ... Even the subject of "Calculation I" which was one of the first and one of the hardest of the semester and that demanded time to study. The teacher of this subject was able to motivate me more and generated more knowledge. I kept that knowledge for the rest of the course. Of course, had the area of "AutoCAD" for example, was one of the subjects that I got involved, and I had a good exchange of information, and knowledge. This encourages people to go for it. Today I no longer work with AutoCAD, but I loved the subject. (Student of the 5 th year)

The social environment in a classroom, the nature and the quality of interactions between students and between the teacher and students can have a profound effect on the quality of learning that takes place in the classroom. If students believe that teachers are concerned about them and have a strong desire for them to learn the content of their subjects, the effects on their motivation to learn and their attitudes about the course, and the topic will increase considerably.

\section{Discussion of Results and Conclusions}

The objective of this article was to identify the perception of Brazilian engineering students', about the relevance of pedagogical knowledge and its implications for the professional preparation.

Starting from students' perception on issues that affect the training of future professionals is a valuable exercise in understanding the teaching learning process practiced in engineering courses, which while have a traditional heritage based on technicalities, need to move forward and introduce new teaching strategies consistent with the changes that have occurred in all sectors of society.

The data analyzed, points out that students' understanding of the relevance of the teaching role in their preparation from issues such as the didactics used by teachers, students' active participation, the contextualization of the content, the relationship between theory and practice and what mean for them a productive or unproductive class, moves away from what characterizes the traditional teaching, such as memorization of formulas, the distance between teacher and student and the disconnection between the theoretical knowledge learned and its application in the real world.

In the statements, students emphasized repeatedly that active participation in the teaching and learning process helps them to reach their own conclusions, to discuss possible options for solving problems, and that makes a difference in learning. It is very clear also in the statements, that to mere expose the content to students, without having them questioning, visualizing its applications, often turns out to be harmless, leading students to seek other strategies that lead them to really understand the content.

The lack of teachers' interest on student learning also marked the accounts. Students believe that teachers interest, their organization, and their effort to study and to research, combined with a good relationship between teachers and students, also contributes to increase learning. 
It is important to note that the issues identified by the students in this study demonstrate the need to upgrade teachers and course curricula, increasingly, using current and innovative teaching strategies for training engineers, valuing the educational and participatory planning in elaboration of criteria and teaching objectives.

Teachers need to reflect on their teaching practices and to conform to the changes that new times demand. They also need to direct students' to self-knowledge and certainty that learning also depends on their attitudes, as subjects of their own learning.

However, maintained the prevalence of lectures via the projection of slides as the main teaching strategy, very little will be done to change the status quo for learning, and for the suggestions issued by the National Curriculum Guidelines for Undergraduate Course Engineering (BRAZIL, 2002), although the suggestions are included in every pedagogical project of the courses it becomes benchmarks inadequate to meet the learning needs of students and the current demands of the working world.

We consider that the views expressed by the students in this study can contribute to reflections on the quality of teaching in engineering courses of the researched institution if taken into account, because when we are attentive to the students' voice we can change the pedagogical actions through approaches involving students with their own learning and active teaching strategies that increase satisfaction and safety for the training.

\section{References}

Anastasiou, L. G. C. (2001). Profissionalização continuada do docente da educação superior: um estudo de caso. 24 $4^{\text {a }}$ Reunião da Anped. Caxambu, Minas Gerais, 2001. Retrieved March, 2015 from http://www.cefetes.br/gwadocpub/Pos-Graduacao/Especializa\%C3\%A7\%C3\%A3o\%20e m\%20educa\%C3\%A7\%C3\%A3o\%20EJA/Publica\%C3\%A7\%C3\%B5es/anped2001/text os/t0411074040023.PDF

Anastasiou, L. G. C. e Alves, L. P. (Orgs.) (2006). Processos de ensinagem na universidade: pressupostos para as estratégias de trabalho em aula. 6. ed. Joinville: UNIVILLE.

Asokanthan, S. F. (1997). Active learning methods for teaching dynamics: development and implementation. ASEE/IEEE Frontiers in Education Conference, 2000 Retrieved September 2011from: http://fie conference.org/fie97/papers/1387.pdf

Barbosa, E. F. e Moura, D. G. (2013). Metodologias ativas de aprendizagem na educação profissional e tecnológica. Boletim Técnico do Senac, 39(2), 48-67.

Bonwell, C. C. (2015). Active learning: creating excitement in the classroom. Retrieved March 2015 from https://www.ydae.purdue.edu/lct/HBCU/documents/Active_Learning_Creating_Excitem ent_in_the_Classroom.pdf

Bordenave, J. D. e Pereira, A. M. (2002). Estratégias de ensino-aprendizagem(24th ed.). 
Petrópolis: Vozes.

Brasil. (2002). Resolução CNE/CES 11, de 11 de março de 2002. Institui Diretrizes Curriculares Nacionais do Curso de Graduação em Engenharia. Retrieved December 2014 from: http://portal.mec.gov.br/cne/arquivos/pdf/CES112002.pdf

Castanho, M. E. L. M. Professores e Inovações. (2000). In: S. Castanho, e M. E. L. M Castanho (Orgs.). O que há de novo na educação superior: do projeto pedagógico à prática transformadora. Campinas: Papirus (Coleção Magistério: Formação e Trabalho Pedagógico). p. 75-94.

Cunha, M. I. (2005). O professor universitário na transição de paradigmas (2nd ed.). São Paulo: Junqueira \& Martins Editores.

Cunha, M. I. (2010). A qualidade da educação superior no Brasil no contexto da democratização: Desafios e perspectivas. Congresso da LASA (Associação de Estudos Latino-Americanos), Toronto, Canadá. Retrieved September 2011 from: http://lasa.international.pitt.edu/members/congress-papers/lasa2010/files/2768.pdf

Duch, B. J., Groh, S. E. e Allen, D. E. (2001). Why problem-based learning? A case study of institutional change in undergraduate education. In: Duch, B. J. et al. (eds.), The Power of problem-based learning. Sterling: Stylus, p.3-11.

Göl, Ö. e Nafalski, A. (2007). Collaborative learning in engineering education. Global J. of Eng. Educ., 11(2).

Henard, F. e Leprince-Ringuet, S. (2008). The path to quality teaching in higher education. OCDE. Retrieved October 2013 from: www.oecd.org/edu/imhe/44150246.pdf

Krivickas, R. V. (2005). Active learning at Kaunas University of Technology. Global Journal of Engineering Education, 9(1), p.43-47. Retrieved September 2011 from http://www.wiete.com.au/journals/GJEE/Publish/vo19no1/Krivickas.pdf

Leite, D. (2008). Qualidade epistemológica nas práticas docentes informadas pela ação da pesquisa. Porto Alegre: EDIPUCRS.

Lucarelli, E. (2000). Um desafio institucional: inovação e formação pedagógica do docente universitário. In: S. Castanho, M. E. L. M Castanho (Orgs.), O que há de novo na educação superior: do projeto pedagógico à prática transformadora. Campinas: Papirus. (Coleção Magistério: Formação e Trabalho Pedagógico).

Moreira, H. e Caleffe, L. G. (2008). Metodologia da pesquisa para o professor pesquisador. (2nd. ed.). Rio de Janeiro: Lamparina.

Moreira, H. et al. (2013). Engineering students' perceptions of the pedagogical practice of teachers. International Journal of Education, 5(2), 129-143. http://dx.doi.org/10.5296/ije.v5i2.2509

Moreira, H., Gravonski, I., Fonseca, K. V. O. e Fraile Aranda, A (2012). A visão dos alunos de engenharia sobre a prática pedagógica dos professores. Título: Ensino Superior: 
Inovação e Qualidade na Docência. VII Congresso Iberoamericano de Docência Universitária. 24 a 27 de junho de 2012. Livro de Atas, Editor: CIIE - Centro de Investigação e Intervenção Educativas.

Morin, E. A. (2004). Cabeça bem-feita: repensar a reforma, reformar o pensamento. Rio de Janeiro: Bertrand Brasil.

Neave, G. (1998). The Evaluative State Reconsidered. European Journal of Education, 33(3), $265-284$.

Pachane, G. G. e Pereira, E. M. A. (2004). A importância da formação didático-pedagógica e a construção de um novo perfil para docentes universitários. Revista Iberoamericana de Educación. n. 33/4, Retrieved August 2011 from: http://www.rieoei.org/edu_sup26.htm

Rego, A. (2001). O bom cidadão docente universitário na senda da qualidade no ensino $\begin{array}{lllll}\text { superior. Educação } \quad \& \quad \text { Sociedade, } & \text { 22(75), } & \text { 174-199. }\end{array}$ http://dx.doi.org/10.1590/S0101-73302001000200010.

Silva, L. P. e Cecílio, S. (2007). A mudança no modelo de ensino e formação na engenharia. Educação em Revista. Belo Horizonte, 45, 61-80. http://dx.doi.org/10.1590/S0102-46982007000100004.

Villas-Boas, V. et al. (2012). Aprendizagem ativa na engenharia. In: V.F. Oliveira, Z. Chamberlain, A. Peres, P.R. Brandt e S.L. Schwertl (Orgs), Desafios da educação em engenharia: vocação, formação, exercício profissional, experiências metodológicas e proposições. Brasília/Blumenau: ABENGE/EdiFURB.

\section{Copyright Disclaimer}

Copyright for this article is retained by the author(s), with first publication rights granted to the journal.

This is an open-access article distributed under the terms and conditions of the Creative Commons Attribution license (http://creativecommons.org/licenses/by/3.0/). 